T. С. Іванова ${ }^{1}$, аспірант, провідний інженер

Н. А. Бісько', д.б.н., провідний науковий співробітник

Г. П. Мегалінська ${ }^{3}$, к.б.н., доцент

'Державна установа «Інститут харчової біотехнології та геноміки

Національної академії наук України»,

вул. Осиповського, 2а, Київ, 04123, Україна, тел.: +38 (044) 46272 58,

e-mail: ivanova_tatiana_wat2@bigmir.net

${ }^{2}$ Інститут ботаніки ім. М. Г. Холодного НАН України,

вул. Терещенківська, 2, Київ, 01601, Україна

${ }^{3}$ Національний педагогічний університет імені М. П. Драгоманова;

вул. Пирогова, 9, Київ, 01601, Україна

\title{
ФІЗІОЛОГІЧНА АКТИВНІСТЬ SCHIZOPHYLLUM COMMUNE TA TRAMETES VERSICOLOR ПРИ КУЛЬТИВУВАННІ НА СУХАРНІЙ КРИХТІ
}

\begin{abstract}
Досліджена антимікробна, гемаглютинувальна та фітотоксична активність міцелію Schizophyllum commune 1768 і Trametes versicolor 353, отриманого при глибинному культивуванні на сухарній крихті (відході виробництва хліба). Водні екстракти міцелію досліджуваних видів грибів найбільше інгібували pict Proteus vulgaris. Аглютинування еритроцитів крові людини екстрактами міцелію грибів не відрізнялось від контролю. Встановлена фітотоксична активність водного екстракту міцелію $S$. соттипе на моделі проростків огірка за концентрацій вище 35 мг/мл, екстракту T. versicolor - від 5 до 45 мг/мл.
\end{abstract}

Ключові слова: Shizophyllum commune, Trametes versicolor, фізіологічна активність, сухарна крихта.

Schizophyllum commune Fr.: Fr. (шизофіл звичайний) та Trametes versicolor (L.: Fr.) Quel. (трутовик різнокольоровий) належать до дереворуйнівних грибів відділу Basidiomycota та виявляють цілий спектр лікувальних властивостей, зокрема, імуномоделювальну, протипухлинну, антимікробну та інші активності, а тому використовуються як основа для створення лікувально-профілактичних препаратів [14].

Біохімічний склад та лікувально-профілактичні властивості грибів залежать не лише від виду та штаму, а й від умов та субстрату для культивування. Новим субстратом для культивування міцелію $T$. versicolor та $S$. commune є сухарна крихта - відхід, що утворюється при виробництві хліба. Цей субстрат ефективно утилізується грибами через високий вміст легкодоступних вуглеводів та утворення однорідної суспензії у воді.

Метою роботи було дослідити фізіологічну активність (антимікробну, гемаглютинувальну та фітотоксичну дію) міцелію лікарських базидіальних грибів T. versicolor та $S$. commune, отриманого при культивуванні на сухарній крихті, 
що може бути використаний як основа для створення дієтичних добавок та функціональних продуктів харчування.

\section{Матеріали та методи дослідження}

Штами S. commune 1768 та T. versicolor 353 були отримані з колекції культур шапинкових грибів Інституту ботаніки ім. М. Г. Холодного НАН України (IBK) [1]. Штами бактерій Escherichia coli (Migula 1895) Castellani and Chalmers 1919 ATCC 25922 (кишкова паличка), Proteus vulgaris Hauser, 1885 ATCC 6896 (протей звичайний), Pseudomonas aeruginosa Schroeter 1872, Migula 1900 ATCC 9027 (синьогнійна паличка) та дріжджів Candida albicans (C. P. Robin) Berkhout 1923 АТСС 885-653 (кандіда біліюча) були отримані з Української колекції мікроорганізмів (УКМ) Інституту мікробіології та вірусології ім. Д. К. Заболотного НАН України [10].

Субстратом для глибинного культивування була сухарна крихта з суміші хлібів із пшеничного та житнього борошна (Хлібокомбінат № 12, ПАТ «Київхліб», Київ). Поживні середовища, що містили сухарну крихту та воду, стерилізували 40 хв при 1 атм.

Міцелій грибів вирощували на чашках Петрі з глюкозо-пептон-дріжджовим агаризованим середовищем, г/л: глюкоза - 25 , пептон -3 , дріжджовий екстракт - 2, $\mathrm{KH}_{2} \mathrm{PO}_{4}-1, \mathrm{~K}_{2} \mathrm{HPO}_{4}-1, \mathrm{MgSO}_{4}$ х $7 \mathrm{H}_{2} \mathrm{O}-0,25$, агар-агар - 20. Ceредовище із міцелієм повністю колонізованої чашки Петрі гомогенізували у стерильних умовах, отриманий гомогенат використовували як інокулюм (10\% об./об.) для засіву 250 мл колб Ерленмеєра із 50 мл рідкого середовища 3 сухарною крихтою. Колби інкубували при $28 \pm 2{ }^{\circ} \mathrm{C}$ на качалці при 120 об./хв. Мiцелій в активній фазі росту пересівали (10 \% об./об.) на середовище такого ж складу для елімінування лаг-фази. Міцелій грибів вирощували на поживному середовищі з оптимальною для накопичення біомаси концентрацією сухарної крихти (50 г/л для T. versicolor та 60 г/л для S. commune) [12]. Для отримання максимальної біомаси міцелій $T$. versicolor культивували 5 діб, міцелій $S$. commипе - 4 доби. Біомасу відділяли від культуральної рідини фільтруванням, промивали 3 рази водою, висушували при $60^{\circ} \mathrm{C}$ та перемелювали.

Для визначення гемаглютинувальної активності готували лектиновмісну витяжку. До 1 г сухого міцелію $S$. commune або T. versicolor додавали 10 мл $0,9 \% \mathrm{NaCl}$, перемішували 2 години, центрифугували при 6000 об./хв та фільтрували. Додавали 10 мл лектиновмісної витяжки у співвідношенні 1:1 до крові людини чотирьох груп, перемішували та відстоювали 1 годину в капілярах Панченкова, після чого вимірювали ступень осадження еритроцитів (мм) у порівнянні з контролем (кров чотирьох груп без додавання витяжки міцелію) [7].

Для визначення антимікробної та фітотоксичної активності отримували водний екстракт міцелію $S$. commune та $T$. versicolor. До 5 г сухого міцелію додавали 100 мл дистильованої води та кип'ятили 3 хв [6]. Антимікробну ак- 
тивність отриманих екстрактів перевіряли методом паперових дисків (діаметр диску 5 мм) [17].

Визначення фітотоксичної активності вищезазначених екстрактів проводили за описаною методикою [5]. Тест-об' єктом був Cucumis sativus L. (огірок звичайний), для якого характерним є ранній розвиток бічних коренів. Насіння огірка сорту «Ніжинський» розкладали по 10 шт. на фільтрувальний папір у чашки Петрі та заливали 10 мл розчину екстрактів у дистильованій воді у співвідношенні від 1:9 до 9:1, що відповідає концентраціям біомаси для отримання екстрактів від 5 до 45 мг/мл. Контролем вважали дистильовану воду. Кількість бічних вимірювали після 10 діб інкубування насіння огірка при $20 \pm 2{ }^{\circ} \mathrm{C}$.

Повторність дослідів трикратна. Числові дані представлені в формі середньої величини зі стандартною похибкою $(\mathrm{M} \pm \mathrm{m})$. Достовірність різниці двох середніх величин оцінювали за критерієм Стьюдента (t).

\section{Результати дослідження та їх обговорення}

Отримані результати свідчать про те, що водні екстракти міцелію $S$. commune та T. versicolor, культивованого на сухарній крихті, виявляли інгібувальну активність (зони просвітлення становили 6,9-9,2 мм) стосовно досліджуваних видів мікроорганізмів (табл. 1). Найбільшою мірою водні екстракти міцелію $S$. commune та $T$. versicolor пригнічували ріст $P$. vulgaris.

Таблиця 1

Антимікробна активність водних екстрактів міцелію

T. versicolor 353 та $S$. commune 1768

\begin{tabular}{|l|c|c|c|c|}
\hline \multirow{2}{*}{ Вид гриба } & \multicolumn{4}{|c|}{ Зона інгібування росту мікроорганізмів, мм } \\
\cline { 1 - 5 } & E. coli & P. vulgaris & P. aeruginosa & C. albicans \\
\hline T. versicolor & $\mathbf{7 , 2} \pm \mathbf{0 , 3}$ & $\mathbf{8 , 2} \pm \mathbf{0 , 3}$ & $\mathbf{6 , 9} \pm \mathbf{0 , 4}$ & $\mathbf{7 , 1} \pm \mathbf{0 , 4}$ \\
\hline S. commune & $\mathbf{7 , 2} \pm \mathbf{0 , 3}$ & $\mathbf{9 , 2} \pm \mathbf{0 , 3}$ & $\mathbf{7 , 1} \pm \mathbf{0 , 4}$ & $\mathbf{8 , 1} \pm \mathbf{0 , 4}$ \\
\hline
\end{tabular}

Примітка: всі значення достовірно відрізняються від контролю (відсутність зон інгібування) $\mathrm{p}<0,05$.

Інші дослідники встановили, що водні екстракти міцелію T. versicolor, отриманого при глибинному культивуванні на глюкозо-пептоно-дріжджовому середовищі, виявили слабку антибактеріальну активність (< 10 мм) до E. coli, але, на відміну від отриманих даних, не виявили антимікробної активності до $P$. aeruginosa, та $C$. albicans [19]. Екстракти плодових тіл $S$. commune гарячою водою не виявили антимікробної активності до E. coli, P. vulgaris та P. aeruginosa [13].

Встановлено [18], що лектини лікарських грибів не тільки здатні викликати апоптоз у пухлинних клітинах та пришвидшувати мітоз імунокомпетентних 
клітин, а також мають антимікробну активність [9]. Водночас, вважається [16], що лектини грибів, які склеюють специфічні для чотирьох груп крові вуглеводні детермінанти на поверхні клітин організму людини, можуть негативно впливати на здоров'я. Показано, що гемаглютинувальна активність грибних екстрактів залежить від таксономічної належності культур, способу культивування (рідинне, твердофазне) та від складу поживного середовища [2]. При цьому, відмічається [2] значне підвищення лектинової активності при використанні субстратів, несприятливих для росту міцелію, що, ймовірно, має адаптивне значення.

Екстракти міцелію T. versicolor 353 та S. commune 1768, одержані при глибинному культивуванні на поживному середовищі з сухарною крихтою, не виявляли гемаглютинувальну активність до чотирьох груп крові людини (табл. 2).

Таблиця 2

Гемаглютинувальна активність $T$. versicolor 353 та $S$. commune 1768

\begin{tabular}{|l|c|c|c|c|c|}
\hline \multirow{2}{*}{ Екстракт } & \multicolumn{5}{|c|}{ Осадження еритроцитів, мм } \\
\cline { 2 - 6 } & \multirow{2}{*}{ Контроль } & $\begin{array}{c}\text { I група } \\
\text { крові }\end{array}$ & $\begin{array}{c}\text { II група } \\
\text { крові }\end{array}$ & $\begin{array}{c}\text { III група } \\
\text { крові }\end{array}$ & $\begin{array}{c}\text { IV група } \\
\text { кровi }\end{array}$ \\
\cline { 1 - 6 } Міцелій T. versicolor & \multirow{2}{*}{$2 \pm 1$} & $3 \pm 1$ & $3 \pm 1$ & $2 \pm 1$ & $2 \pm 1$ \\
\cline { 1 - 4 } Міцелій S. commune & & $2 \pm 1$ & $2 \pm 1$ & $2 \pm 1$ & $2 \pm 1$ \\
\hline
\end{tabular}

Примітка: значення не відрізняються від контролю та між собою, $<<0,05$.

Згідно з літературними даними, вивчали гемаглютинувальну активність переважно екстрактів плодових тіл різних видів грибів [15]. Зокрема показано, що екстракти T. versicolor не спричинювали аглютинацію еритроцитів чотирьох груп крові людини, на відміну від екстрактів $S$. соттипе, які викликали аглютинацію без групової селективності $[15,11]$. Попередніми дослідженнями виявлено, що екстракт міцелію Ganoderma lucidum (трутовик лакований), отриманий при поверхневому культивуванні на рідкому середовищі зі шротом амаранту, викликав аглютинування еритроцитів чотирьох груп крові людини [3].

Для скринінгу цитостатичної активності сполук зручним тест-об'єктом є утворення бічних коренів рослин (що здійснюється за рахунок мітозу) внаслідок простоти обробки розчинами досліджуваних сполук, більш легкого проникнення їх усередину кореня, а також вищої чутливості клітин коренів до більшості токсичних речовин, у порівнянні з наземними органами рослин [4].

Результати досліджень показали (рис. 1), що водний екстракт міцелію S. commune 1768 за концентрацій більше 35 мг/мл виявляє фітотоксичну активність (на 36-50 \% зменшилась кількість бічних коренів порівняно з контролем). 


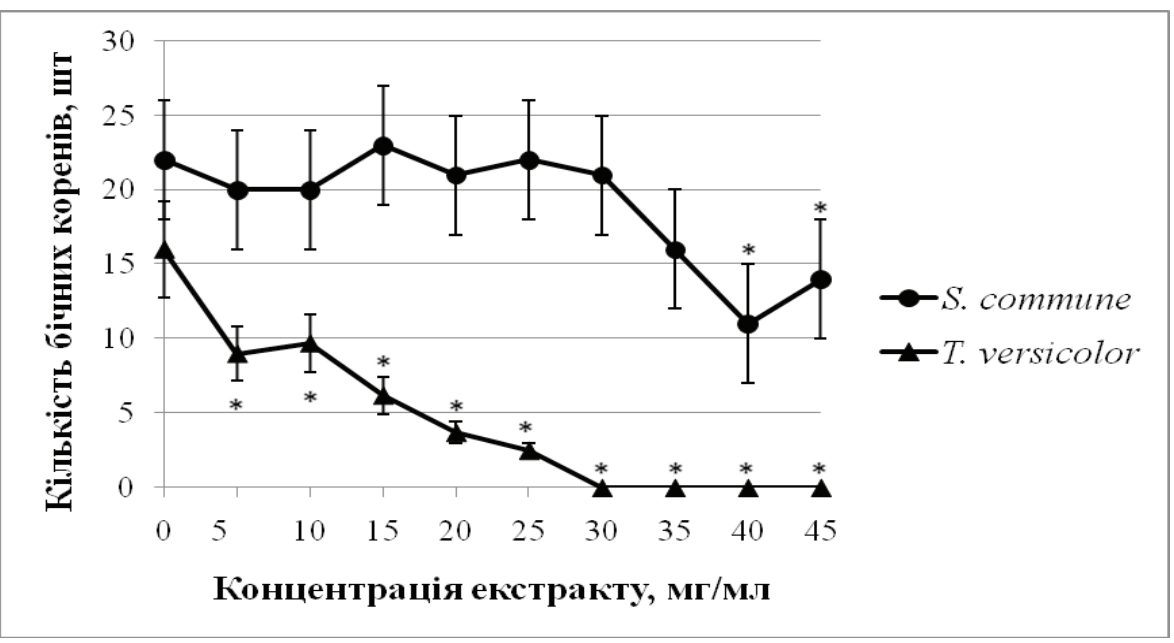

Рис. 1. Вплив концентрації водних екстрактів міџелію T. versicolor 353 ma S. соттипе 1768 на кількість бічних коренів огірка (0 - контроль, вода)

Примітка: * - значення достовірно відрізняються від контролю, $<<0,05$.

Екстракт міцелію T. versicolor 353 виявив значно більшу фітотоксичну активність, достовірно $(\mathrm{p}<0,05)$ в порівнянні $з$ контролем зменшуючи кількість бічних коренів за всіх концентрацій екстракту від 5 до 45 мг/мл (рис. 1), при цьому кількість бічних коренів зменшувалась на 39-100 \% (за концентрацій 30-45 мг/мл спостерігалося повне інгібування утворення бічних коренів).

Згідно з іншими дослідженнями, лектиновмісні екстракти плодових тіл Agaricus bisporus (печериці двоспорової) та Boletus edulis (білого гриба) мали більш виражену фітотоксичну активність, ніж листя рослин родів Magnolia (магнолія) та Rumex (щавель), і повністю інгібували утворення бічних коренів на моделі проростків огірка при концентрації розбавлення екстракту 40 мг/мл [8].

\section{Висновки}

1. Екстракти гарячою водою міцелію S. commune 353 та T. versicolor 1768 при культивуванні на сухарній крихті виявляли слабку антимікробну активність до досліджуваних культур, при цьому найбільше інгібувався ріст $P$. vulgaris (зона затримки росту 8,2 $\pm 0,3$ та 9,2 $\pm 0,3$ мм відповідно).

2. Вперше була виявлена відсутність гемаглютинувальної активності екстрактів міцелію $S$. commune 1768 та T. versicolor 353, отриманої при культивуванні на сухарній крихті, що збільшує цінність використання міцеліальної маси цих грибів для створення дієтичних добавок та функціональних продуктів харчування без негативного впливу на здоров'я людини. 
3. Вперше досліджена фітотоксична активність водних екстрактів міцелію S. commune 1768 та T. versicolor 353 на моделі коренів огірка та показано, що екстракт міцелію $T$. versicolor мав більш виражену фітотоксичну активність, ніж S. commune.

4. Глибинне культивування S. commune 1768 та T. versicolor 353 на дешевих та безпечних для здоров'я людини відходах виробництва хліба - сухарній крихті дозволяє отримати біомасу лікарських грибів з антимікробними та фітотоксичними властивостями.

\section{Список використаної літератури}

1. Бухало А. С. Каталог колекції культур шапинкових грибів (IBK) / А. С. Бухало, Н. Ю. Митропольская, О. Б. Михайлова. - К.: Альтерпрес, 2011. - 100 с

2. Ветчинкина Е. П. Активность внутриклеточных лектинов Lentinus edodes на разных стадиях развития гриба при глубинном и твердофазном культивировании / Е. П. Ветчинкина, В. Е. Никитина // Известия Самарского научного центра РАН. - 2008. - Т. 10. - № 2. - С. 629-635.

3. Іванова T. Гемаглютинуюча й антибактеріальна активність лектиновмісної витяжки Ganoderma lucidum / Т. Іванова, Г. Мегалінська, Т. Круподьорова // Молодь і поступ біології: VII Міжнар. наук. конф. студентів і аспірантів, 5-8 квітня 2011 р. - Львів, 2011. - С. 50-51.

4. Иванов В. Б. Использование корней как тест-объектов для оценки биологического действия химических соединений / В. Б. Иванов // Физиология растений. - 2011. - Т. 58, № 6. - С. 944-952.

5. Иванов В. Б. Проростки огурца как тест-объект для обнаружения эффективных цитостатиков / В. Б. Иванов, Е. И. Быстрова, И. Г. Дубровский // Физиология растений. - 1986. - Т. 33, № 1. - С. 195-199.

6. Лікарські рослини: [енциклопедичний довідник] / під ред. А. М. Гродзінського. - К.: Українська Енциклопедія, 1992. - 544 с.

7. Луиик А. Д. Лектины / А. Д. Луцик, Е. Н. Панасюк, М. Д. Луцик. - Львов: Высшая школа, 1981. - 156 с.

8. Мегалінська Г. П. Літична, антибактеріальна та цитостатична активність лектинів деяких лікарських рослин / Г. П. Мегалінська, К. П. Ільєнко, Н. У. Желтовська // Природничі науки на межі століть: матеріали наук.-практ. конф., 23-25 бер. 2004. - Ніжин, 2004. - С. 64-65.

9. Paпопорт E. M. Выделение и характеристика галактозосвязывающих лектинов из сыворотки крови человека / Е. М. Рапопорт, Л. С. Жигис, Е. Ю. Корчагина, Т. В. Овчинникова, В. П. Зубов, Н. В. Бовин // Биоорганическая химия. - 1996. - Т. 22, № 5. - С. 353-357.

10. Украинская коллекция микроорганизмов. Каталог культур / Под ред. В. С. Подгорского, О. И. Коцофляк, Е. А. Киприановой, О. Р. Гвоздяк. - К.: Наукова думка, 2007. - 270 с.

11. Chumkhunthod P. Lectins from Tropical Mushrooms: A Thesis Submitted in Partial Fulfillment of the Requirements for the Degree of Doctor of Philosophy in Microbiology / Podjana Chumkhunthod. - Nakhon Ratchosima, Thailand, 2004. - $208 \mathrm{p}$.

12. Ivanova T. S. Breadcrumb as a New Substrate for Trametes versicolor and Schizophyllum commune Submerged Cultivation / T. S. Ivanova, N. A. Bisko, T. A. Krupodorova, V. Yu. Barshteyn // Korean J Microbiol Biotechnol. - 2014. - Vol. 42 (1). - P. 67-72.

13. Mirfat A. H. S. Antimicrobial activities of split gill mushroom Schizophyllum commune Fr. / A. H. S. Mirfat, A. Noorlidah, S. Vikineswary // American Journal of Research Communication. - 2014. - Vol. 2 (7). - P. 113124.

14. Mushrooms as Functional Foods / ed. by P. C. K. Cheung. - New York: Wiley, 2008. - 259 p

15. Pemberton R. T. Agglutinins (lectins) from some British higher fungi / R. T. Pemberton // Mycol Res. - 1994. Vol. 98 (3). - P. 277-290.

16. The Biology and Cultivation of Edible Mushrooms / ed. by S. T. Chang, W. A. Hayes. - New York: Academic Press. - 1978. - P. 137-168.

17. Valgas $C$. Screening methods to determine antibacterial activity of natural products / C. Valgas, S. M. de Souza, E. F. A. Smania, A. Smania // Brazilian Journal of Microbiology. - 2007. - Vol. 38. - P. 369-380

18. $X u$ X. Bioactive proteins form mushrooms / X. Xu, H. Yan, J. Chen, X. Zhang // Biotechnology Advances. 2011. - Vol. 29. - P. 667-674.

19. Yamac M. Antimicrobial Activities of Fruit Bodies and/or Mycelial Cultures of Some Mushroom Isolates / M. Yamac, F. Bilgili // Pharm Biol. - 2006. - Vol. 44 (9). - P. 660-667.

Стаття надійшла до редакції 15.06.2015 
Т. С. Иванова ${ }^{1}$, Н. А. Бисько ${ }^{2}$, А. П. Мегалинская ${ }^{3}$

${ }^{1}$ Государственное учреждение «Институт пищевой биотехнологии и геномики Национальной академии наук Украины», ул. Осиповского, 2а,

Киев, 04123, Украина

${ }^{2}$ Институт ботаники им. Н.Г. Холодного НАН Украины, ул. Терещенковская, 2 , Киев, 01601, Украина

${ }^{3}$ Национальный педагогический университет имени М.П. Драгоманова,

ул. Пирогова, 9, Киев, 01601, Украина

\title{
ФИЗИОЛОГИЧЕСКАЯ АКТИВНОСТЬ SHIZOPHYLLUM COMMUNE И TRAMETES VERSICOLOR ПРИ КУЛЬТИВИРОВАНИИ НА СУХАРНОЙ КРОШКЕ
}

\begin{abstract}
Резюме
Исследована антимикробная, гемагглютинирующая и фитотоксическая активность мицелия Schizophyllum commune 1768 и Trametes versicolor 353, полученного при глубинном культивировании на сухарной крошке (отходе производства хлеба). Экстракты исследованных грибов более всего ингибировали рост Proteus vulgaris; гемагглютинация эритроцитов крови человека экстрактами мицелия грибов не отличалось от контроля. Экстракт мицелия S. соттипе показал цитостатическую активность на модели проростков огурца при концентрациях выше 35 мг/мл, экстракт T. versicolor - при всех концентрациях.
\end{abstract}

Ключевые слова: Shizophyllum commune, Trametes versicolor, физиологическая активность, сухарная крошка.

\section{T. S. Ivanova ${ }^{1}$, T. S. Biskoч ${ }^{2}$, G. P. Megalinska ${ }^{3}$}

${ }^{1}$ Institute of Food Biotechnology and Genomics NAS of Ukraine, 2A, Osipovskogo St., Kyiv, 04123, Ukraine

${ }^{2} \mathrm{M}$. G. Kholodny Institute of Botany NAS of Ukraine, 2, Tereshchenkivska St., Kyiv, 01601, Ukraine

${ }^{3}$ National Pedagogical M. P. Dragomanov University, 9, Pirogova St., Kyiv, 01601, Ukraine

\section{PHYSIOLOGICAL ACTIVITY OF SHIZOPHYLLUM COMMUNE FR.: FR. AND TRAMETES VERSICOLOR (L.: FR.) QUEL. CULTIVATED ON BREADCRUMB IN SUBMERGED CULTURE}

\begin{abstract}
Shizophyllum commune and Trametes versicolor are well-known medicinal fungi which belong to phylum Basidiomycota and possess immunomodulating, antimicrobial and anticancer activity. The aim of current study was to investigate physiological activity (antimicrobial, hemagglutinating, and phytotoxic effect) of S. commune 1768 and T. versicolor 353 mycelia grown in submerged conditions on breadcrumb (waste of bread production), which ccan be used for creation of dietary supplements and functional foods. Antimicrobial activity of $S$. commune and $T$. versicolor hot water extracts was evaluated toward Escherichia coli ATCC 25922, Proteus vulgaris
\end{abstract}


ATCC 6896, Pseudomonas aeruginosa ATCC 9027 and Candida albicans ATCC 885-653 using paper disc method. Hemagglutinating activity was measured by comparing the velocity of erythrocyte sedimentation in human blood groups (ABO) after addition of $S$. commune and $T$. versicolor extracts and in control (without addition of fungal extracts). Phytotoxic activity of $S$. commune and $T$. versicolor was investigated using inhibition of lateral roots emerging in Cucumis sativus L. seedlings as model. Our findings have shown that $S$. commune and $T$. versicolor cultivated in submerged conditions on breadcrumb exhibited similar physiological activity: the highest inhibition rates of fungal extracts were shown toward P. vulgaris; human erythrocyte hemagglutination with crude mycelia extracts didn't significantly differ from control. At the same time, $S$. commune hot water extract showed phytotoxic activity at concentrations higher $35 \mathrm{mg} / \mathrm{ml}$, though $T$. versicolor hot water extract exhibited phytotoxic activity at all concentrations. The mycelia of $S$. commune and T. versicolor grown in submerged culture on breadcrumb possess antimicrobial and phytotoxic activity and can be assumed a safe base for dietary supplements and functional foods.

Key words: Shizophyllum commune, Trametes versicolor, physiological activity, breadcrumb. 